\title{
The Synthesis of Edible Film from Tilapia Fish (Oreochromis niloticus) Bones for Ecofriendly Material of Halal Packaging Applications
}

\author{
Neneng Windayani ${ }^{1,2 *}$, Ferli S. Irwansyah ${ }^{1}$, Meilla N. Effendi ${ }^{1}$ \\ ${ }^{l}$ Departement of Chemistry Education, UIN Sunan Gunung Djati Bandung, Jl. AH. Nasution No. 105 Cibiru, \\ Bandung 40614, Indonesia \\ ${ }^{2}$ Integrated Laboratory UIN Sunan Gunung Djati Bandung, Jl. AH. Nasution No. 105 Cibiru, Bandung 40614, \\ Indonesia \\ e-mail: nenengwinda.ftk@uinsgd.ac.id ${ }^{* 1}$, ferli@uinsgd.ac.id ${ }^{2}$, meilla@gmail.com $^{1}$
}

*Correspondent Author

\begin{abstract}
Packaging materials, especially in food is the most important of healthy aspect. However, today many types of packaging materials used are hazardous to health and environment, then was found alternative halal packaging materials that are safe for health and environment. One of the alternatives is edible film, synthesis from tilapia bone gelatin, it is using sorbitol as plasticizer. Edible film synthesized by dissolving tilapia fish (Oreochromis niloticus) from bone gelatin in distilled water containing sorbitol, then stirred, poured on flat glass, and heated at $50^{\circ} \mathrm{C}$. The procedure is performed with a concentration of gelatin $(8 \%$ and $10 \% \mathrm{w} / \mathrm{v})$ and sorbitol $(25 \%$ and $37 \% \mathrm{v} / \mathrm{v})$. Then was characterized it is mechanical properties include thickness, tensile strength, and elongation to determine eligibility. The optimum condition of the edible film was obtained from $10 \%$ concentration of gelatin with $37 \%$ sorbitol, with the character of it is mechanical properties value are $0.05 \mathrm{~mm}$ thickness, 3,07 MPa tensile strength, and $64.34 \%$ elongation.
\end{abstract}

Keywords: edible film, gelatin, sorbitol, tilapia bone

\section{Introduction}

Religious belief is one of the factors that influence product purchase decisions (Talib \& Johan, 2012). For a Muslim, the halalness of the selected product is one of the considerations. Global halal trends have increased, not only for food products but also in various other products such as clothing, medicines, cosmetics, finance, and even tourism (Talib \& Johan, 2012). This increase is evident in the large demand for halal products in the global market, for example in food products whose value is not less than USD600 billion. This happens because besides being consumed by Muslims with a population of more than 1.5 billion people, halal food is also consumed by non-Muslims, because halal food products are cleaner, healthier, and tastier.

The use of the term halal in food is not only related to the raw materials used, but also to the preparation, process, packaging, transportation and storage (Ashadi, 2015). The halal context in the packaging aspect, aims to protect goods from any cross-contamination between halal and non-halal materials. In addition, packaging also functions as protection from all damage to halal products so that they remain in halal status during transportation, distribution, storage until they reach consumers. The second role of packaging is the marketing function. Packaging is basically used in marketing for the purpose of packaging sales, attracting end consumers and strengthening the product image. Packaging is also the most important factor in purchasing decisions for a product (Talib \& Johan, 2012).

In general, food product packaging is made of plastic. However, recently there have been a number of efforts to reduce the use of plastics because they are considered dangerous or not environmentally friendly. Therefore, food packaging technology has switched to using materials that are more environmentally friendly and even edible, so as to reduce waste generation from food packaging. The alternative packaging materials that are safe for health and the environment, that material is edible film, synthesis from a gelatin. Gelatin has the properties to form a thin elastic layer, forming a film that is transparent and powerful, has the properties of high digestibility as well as safe for health and safe for the environment because it is easily biodegradable. A common commercial gelatin produced from pork, but it is not halal for muslim. Therefore, an alternative source is needed to obtain halal gelatin, one of which comes from fish bones (Herpandi, Huda, \& Adzitey, 2011). In the fish processing process, 
bones, scales, and fins are usually waste, even though the amount can reach $30 \%$ of the total mass of fish (Zakaria \& Bakar, 2015).

Alternative source of gelatin that can be used is from tilapia bone gelatin because the hard fish bones contains $15-17 \%$ collagen (Fitriyani, Nuraenah, Lasmi, \& Nofreena, 2019). Therefore, more research is needed to synthesis of edible film from tilapia bone gelatin with plasticizer sorbitol. Edible films are elastic, not stiff, protected from damage and can be obtained through the addition of plasticizers (Julianto, Ustadi, \& Husni, 2011). Platicizer is a compound that has a small molecular weight that can be added to the edible film to increase flexibility and mechanical properties of edible film (Kramer, 2009). Platicizer commonly used in the synthesis of edible film from gelatin is glycerol, sorbitol, triethylene glycol, glucose, and polyethylene glycol (Julianto et al., 2011). The addition of a plasticizer is to obtain the highest value of the extension. This research conducted to determine the optimal conditions edible film of tilapia (O. niloticus) bone gelatin using a plasticizer sorbitol as ecofriendly of halal packaging application.

\section{Materials and Methods}

\subsection{Materials}

The raw materials of tilapia bones used in this study were obtained from tilapia fish (O. niloticus) purchased from Bandung local market, West Java, Indonesia. Other materials are hydrochloric acid ( $\mathrm{HCl}$ 5\%), distilled water, and sorbitol obtained from Pudak Scientific, Bandung West Java.

\subsection{Experimental Procedures}

\subsubsection{Gelatin Extraction of Tilapia Bone}

The extraction of gelatin from tilapia bone refers to (Deanti et al., 2018) with some modification, includes four stages, that are degreasing, demineralization, extraction, and drying. At first, tilapia bones cleaned from flesh which is still attached to fish bone with cooked for 30 minutes at a temperature of $30-80^{\circ} \mathrm{C}$. After fish bone is cooked then separated from the flesh. The size of fishbone was reduced in to the size of $1-2 \mathrm{~cm}$ to enlarge the surface area. Bones have been eliminated it's oil, then demineralization by soaking in a solution of $5 \% \mathrm{HCl}$ for 48 hours to form ossein. Ossein is washed using distilled water until it has a neutral $\mathrm{pH}$. For further ossein which has had a neutral $\mathrm{pH}$ put in a beaker and added with distilled water with ratio of distilled water and ossein are 1: $3(\mathrm{w} / \mathrm{v})$. After that, ossein heated in a water bath at a temperature of $90^{\circ} \mathrm{C}$ for 7 hours before filterred. The filtrate was dried using freezedry technic to form gelatin powder.

\subsubsection{Analysis of Gelatin}

Gelatin is obtained was reacted with a solution of $\mathrm{NaOH}$ and $\mathrm{CuSO}_{4}$ and $\mathrm{K}_{2} \mathrm{Cr}_{2} \mathrm{O}_{7}$ to prove that the results from freezedry is positive gelatin. 0.1 grams gelatin was tested by dissolving distilled water in a test tube. $1 \mathrm{~mL} \mathrm{NaOH}$ and $2 \mathrm{~mL} \mathrm{CuSO}_{4}$ was added. If solution produced purple color, it was positive solution of gelatin. To further assure that the results obtained are gelatin, then do other evidence by reacting gelatin with $\mathrm{K}_{2} \mathrm{Cr}_{2} \mathrm{O}_{7}$. 0.1 grams gelatin was tested by dissolving distilled water in a test tube and then added about $3 \mathrm{~mL} \mathrm{~K}_{2} \mathrm{Cr}_{2} \mathrm{O}_{7}$. A yellow precipitate that is formed indicates a positive presence of gelatin.

\subsubsection{Edible Film Synthesis from Tilapia Bones Gelatin}

Edible films made from tilapia bone gelatin with the addition of sorbitol as a plasticizer. The concentration of gelatin is $8 \%$ and $10 \%(\mathrm{w} / \mathrm{v})$ and the concentration of sorbitol used was $25 \%$ and $37 \%$. The process of synthesis edible film begins by dissolving sorbitol in water then heating at $70^{\circ} \mathrm{C}$, and stirring during the heating process. Gelatin was added until dissolved. Homogeneous solution was poured onto a glass plate. Then drying on an oven at $50^{\circ} \mathrm{C}$.

\subsubsection{Characterization Edible Film Synthesis from Tilapia (O. niloticus) Bones Gelatin}

Edible film thickness measurement uses a micrometers. Edible film thickness individually determined from the average. The unit used is millimeters $(\mathrm{mm})$. Tensile strength test and this extension using Tensolab 5000. The steps of this measurement are the end of samples was clipped by the tensile testing machine and then the length and thickness of the initial samples are recorded. Pressed the start 
button on the computer and then the tool will pull the sample until the sample broke. The tensile strength can be calculated by the following equation:

Information:

$$
\tau=\frac{F \max }{A}
$$

$\tau \quad$ : tensile strength (MPa)

$\mathrm{F}_{\max } \quad$ : maximum force $(\mathrm{N})$

A : surface area $\left(\mathrm{mm}^{2}\right)$

Measurement of the extension is the same way to the measurement of tensile strength. Extension can be calculated by the following equation:

$$
\text { elongation }(\%)=\frac{\text { end length-inital length }(\mathrm{mm})}{\text { initial length }(\mathrm{mm})} \times 100 \%
$$

\section{Results and Discussion}

Gelatin extraction from tilapia (O. niloticus) bones was carried out in several stages. First, the tilapia bones that have been separated from the meat are heated in water with a temperature of $80^{\circ} \mathrm{C}$ for 30 minutes. This aims to remove fat from the tilapia fish bones. The choice of temperature at $80^{\circ} \mathrm{C}$ is based on the temperature of fat freezing (Rahayu \& Fithriyah, 2015). The next stage is demineralization or removal of calcium salts present in tilapia bones. Tilapia bones are immersed in a $5 \% \mathrm{HCl}$ solution, the ratio of tilapia bones to $\mathrm{HCl}$ is 3: 1 (w / v) for 48 hours until ossein or soft bones are formed. The reactions that occur in the demineralization process are as follows:

$$
\mathrm{Ca}_{3} \mathrm{PO}_{4}(\mathrm{~s})+6 \mathrm{HCl}(\mathrm{aq}) \rightarrow 3 \mathrm{CaCl}_{3}(\mathrm{aq})+\mathrm{H}_{3} \mathrm{PO}_{4}(\mathrm{~s})
$$

The result of the reaction produces dissolved calcium salts and makes tilapia bones soft. The use of $\mathrm{HCl}$ as a solvent aims to convert collagen into a form suitable for hydrolysis (Martianingsih \& Atmaja, 2010), as well as to break the bonds between carboxyl groups and amide groups in collagen molecules (Siburian, Rochima, Andriani, \& Praseptiangga, 2020)

The next phase is washed by ossein with running water until it has a $\mathrm{pH}$ of 5-6, namely the isoelectric $\mathrm{pH}$ of the non-collagen component (Siburian et al., 2020). Furthermore, ossein extraction was carried out using distilled water in a water bath with a ratio of ossein and distilled water $1: 3(\mathrm{w} / \mathrm{v})$ for 5 hours at a temperature of $90^{\circ} \mathrm{C}$. This process aims to eat away the hydrogen bonds between molecules that are still not completely decomposed when immersed in HCl. Hydrogen bonds that have completely broken down will produce a water-soluble gel (Martianingsih \& Atmaja, 2010). The next step is to separate the gelatin from ossein by filtering it. The gelatin solution that had been filtered was then frozen and frozen for 24 hours. Drying aims to remove water from the gelatin. 158.14 grams of tilapia fish bones can produce 18.35 grams of white color and odorless gelatin powder, so the yield produced is $11.60 \%$. Gelatin was analyzed with $\mathrm{NaOH}$ solution and reacted with $\mathrm{CuSO} 4$. In the second analysis, it was reacted with $\mathrm{K}_{2} \mathrm{Cr}_{2} \mathrm{O}_{7}$ to prove that the result obtained was gelatin.

Optimization of the synthesis edible film from tilapia bone gelatin by using plasticizer sorbitol was done by varying the concentration of gelatin and a sorbitol. The results show at Table 1.

Table 1. The Results of characterization edible film by using plasticizer sorbitol

\begin{tabular}{lcccc}
\hline \multirow{2}{*}{ Mechanic properties } & \multicolumn{4}{c}{ Edible Film } \\
\cline { 2 - 4 } & $\begin{array}{c}\text { Gelatin 8\% } \\
\text { Sorbitol 25\% }\end{array}$ & $\begin{array}{c}\text { Gelatin 8\% } \\
\text { Sorbitol 37\% }\end{array}$ & $\begin{array}{c}\text { Gelatin 10\% } \\
\text { Sorbitol 25\% }\end{array}$ & $\begin{array}{c}\text { Gelatin 10\% } \\
\text { Sorbitol 37\% }\end{array}$ \\
\hline Thickness (mm) & 0.050 & 0.059 & 0.049 & 0.045 \\
Tensile strength (MPa) & 2.450 & 2.710 & 3.000 & 3.070 \\
Elongation (\%) & 51.66 & 62.66 & 59.33 & 64.34 \\
\hline
\end{tabular}

Based on the characterization results (Table 1), the optimum conditions for making edible films from tilapia bone gelatin were obtained in the addition of $10 \%$ gelatin and $37 \%$ sorbitol. The data in Table 1 also shows that in small gelatin formulations, the function of sorbitol can be seen as indicated by its greater elongation value, whereas in larger gelatin formulations, the role of sorbitol is less visible 
because gelatin tends to be more active in hydrogen bonding with other monomers on the edible film, as happened in the polyblend film of breadfruit-chitosan starch (Setiani, Sudiarti, \& Rahmidar, 2013).

Table 1 shows that the edible film with a lower gelatin formulation had a higher thickness with the addition of sorbitol, whereas in the formulation with higher gelatin the addition of sorbitol tended to decrease the thickness of the resulting edible film. The increase in sorbitol concentration causes the thickness of the edible film layer to increase. Like water, sorbitol molecules will occupy cavities in the matrix and interact with the polymer (Sudaryati, Mulyani, \& Hansyah, 2010). Meanwhile, the mechanical properties of tensile strength experienced an increase in the addition of sorbitol to both lower and higher gelatin formulations.

The increase in sorbitol levels in each formulation caused an increase in the elongation of the resulting edible film. Sorbitol is a plasticizer which prevents the polymer chains in the edible film matrix from forming a very strong bond so that the ability of the edible film to be stretched decreases. Sorbitol is a hydrophilic plasticizer so that it can interact with the edible film matrix. Its ability to interact will prevent the polymer chains from interacting strongly or crystallizing which can cause the film matrix to become stiff. The results Bourtoom (2008) (Wang, Wei, Chang, Sun, \& Zhu, 2016) research show that an increase in the concentration of plasticizers (sorbitol) results in an increase in elongation at break. This increase in elongation means that there is an increase in the ability of the edible film to be rolled because the edible film has increased its ability to be stretched.

This research is limited to the mechanical characteristics of the edible film produced, therefore further study is needed to determine the characteristic characteristics of the chemical properties and the ability of edible film as a barrier against the environment such as humidity, water, oil, aroma, and mass transfer, so it can be used in halal packaging technology.

\section{Conclusion}

Edible films from tilapia (O. niloticus) bone gelatin have been successfully synthesized under optimum conditions of $10 \%$ gelatin and $37 \%$ sorbitol. The mechanical characteristics of the edibel film produced had a thickness of $0.05 \mathrm{~mm}$, tensile strength of $3.07 \mathrm{MPa}$, and elongation of $64.34 \%$. Further research needs to be carried out to determine its chemical properties and the ability of edible film as a barrier against the environment such as humidity, air, oil, aroma, and mass transfer, so it can be used in halal packaging technology.

\section{Acknowledgement}

We Acknowledge Examination Laboratory Of High School Textiles University Bandung for the support and cooperation to this research project.

\section{References}

Ashadi, R. W. (2015). Halal Science: An Introduction. Journal Of Halal Research, 1(1), 3-5.

Bourtoom, T. (2008). Review Article Edible Films and Coatings: Characteristics and Properties. International Food Research Journal, 15(3), 237-248.

Deanti, H., Hulu, J. M., Setyaji, A., Eliyanti, R. N., Aliya, K., \& Dewi, E. N. (2018). The Quality of Edible Film Made from Nile Tilapia (Oreochromis niloticus) Skin Gelatin with Addition of Different Type Seaweed Hydrocolloid. IOP Conference Series: Earth and Environmental Science, 116(1), 0-7. https://doi.org/10.1088/1755-1315/116/1/012062

Fitriyani, E., Nuraenah, N., Lasmi, L., \& Nofreena, A. (2019). Development of Edible Coating from Gelatin Bone Toman Fish (Channa micropeltes) in Frozen Shrimp. International Journal of Multi Discipline Science (IJ-MDS), 2(1), 19. https://doi.org/10.26737/ij-mds.v2i1.965

Herpandi, Huda, N., \& Adzitey, F. (2011). Fish Bone and Scale as a Potential Source of Halal Gelatin. Journal of Fisheries and Aquatic Science, 6(4), 379-389. https://doi.org/10.3923/jfas.2011.379.389

Julianto, G. E., Ustadi, \& Husni, A. (2011). Karakterisasi Edible Film Dari Gelatin Kulit Nila Merah Dengan Penambahan Plasticizer Sorbitol Dan Asam Palmitat. Jurnal Perikanan (J. Fish. Sci.), 13(1), 27-34. https://doi.org/10.22146/jfs.3059

Kramer, M. E. (2009). Structure and Function of Starch-Based Edible Films and Coatings. In Edible Films and Coatings for Food Applications. https://doi.org/10.1007/978-0-387-92824-1_4

Martianingsih, N., \& Atmaja, L. (2010). Analisis Sifat Kimia, Fisik, dan Termal Gelatin dari Ekstraksi 
Kulit Ikan Pari (Himantura gerradi) Melalui Variasi Jenis Larutan Asam. Prosiding Kimia FMIPA-ITS, 1-9. Surabaya.

Rahayu, F., \& Fithriyah, N. H. (2015). Pengaruh Waktu Ekstraksi Terhadap Rendemen Gelatin dari Tulang Ikan Nila Merah. Prosiding Semnastek, (November), 1-6.

Setiani, W., Sudiarti, T., \& Rahmidar, L. (2013). Preparasi Dan Karakterisasi Edible Film Dari Poliblend Pati Sukun-Kitosan. Jurnal Kimia VALENSI, 3(2). https://doi.org/10.15408/jkv.v3i2.506

Siburian, W. Z., Rochima, E., Andriani, Y., \& Praseptiangga, D. (2020). Fish gelatin (Definition, Manufacture, Analysis of Quality Characteristics, and Application): A Review. International Journal of Fisheries and Aquatic Studies, 8(4), 90-95. Retrieved from http://www.fisheriesjournal.com

Sudaryati, Mulyani, T., \& Hansyah, E. R. (2010). Sifat fisik dan mekanis edible film dari tepung porang (Amorphopallus oncophyllus) dan karboksimetilselulosa. Jurnal Teknologi Pertanian, 11(3), 196201.

Talib, M. S. A., \& Johan, M. R. M. (2012). Issues in Halal Packaging: A Conceptual Paper. International Business and Management, 5(2), 94-98. https://doi.org/10.3968/j.ibm.1923842820120502.1080

Wang, Q., Wei, W., Chang, F., Sun, J., \& Zhu, Q. (2016). Controlling the Size and Film Strength of Individualized Cellulose Nanofibrils Prepared by Combined Enzymatic Pretreatment and High Pressure Microfluidization. Bioresources, 11(1), 2536-2547. https://doi.org/10.3390/polym7061106

Zakaria, S., \& Bakar, N. H. A. (2015). Extraction and Characterization of Gelatin from Black Tilapia (Oreochromis niloticus) Scales and Bones. International Conference on Advances in Science, Engineering, Technology \& Natural Resources (ICASETNR-15), 77-80. Kinabalu (Malaysia).

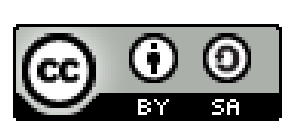

(C) 2020 by the authors. Submitted for possible open access publication under the terms and conditions of the Creative Commons Attribution (CC BY SA) license (https://creativecommons.org/licenses/by-sa/4.0/). 